\title{
SOCIAL SUPPORT AND SOCIAL NETWORK IN FAMILY NURSING: REVIEWING CONCEPTS
}

\author{
Iara Cristina da Silva Pedro ${ }^{1}$ \\ Semiramis Melani Melo Rocha ${ }^{2}$ \\ Lucila Castanheira Nascimento ${ }^{3}$
}

Pedro ICS, Rocha SMM, Nascimento LC. Social support and social network in family nursing: reviewing concepts. Rev Latino-am Enfermagem 2008 março-abril; 16(2):324-7.

Social support and social network concepts are resources applicable to Family Nursing, as they are aimed at improving families' quality of life, and also at promoting, strengthening and maintaining their wellbeing. This study aimed to reflect on the main social network and social support concepts, relating them with Family Nursing, with a view to their application in nursing research and practice. We conclude that there is a lack of consensus about these concepts and that further criteria are needed for their use. In using Family Nursing, researchers must select the most relevant social network and social support concepts in literature to achieve the proposed objectives.

DESCRIPTORS: social support; family nursing; concept formation

\section{RED Y APOYO SOCIAL EN ENFERMERÍA FAMILIAR: REVISIÓN DE CONCEPTOS}

Los conceptos sobre red y apoyo social se constituyen en recursos aplicados en Enfermería Familiar, considerando que su finalidad es mejorar la calidad de vida de las familias, así como promover, fortalecer y mantener su bienestar. El objetivo del estudio fue reflexionar con respecto a los principales conceptos sobre red y apoyo social, los cuales se relacionan con Enfermería Familiar dentro de la investigación y práctica de enfermería. Se concluye que la falta de un consenso sobre estos conceptos, genera la necesidad de utilizar más criterios para su aplicación. Cuando se trabaja con Enfermería Familiar, el investigador debe seleccionar en la bibliografía los conceptos de red y de apoyo social más importante, para alcanzar los objetivos propuestos.

DESCRIPTORES: apoyo social; enfermería de la familia; formación de concepto

\section{APOIO E REDE SOCIAL EM ENFERMAGEM FAMILIAR: REVENDO CONCEITOS}

Os conceitos sobre apoio e rede social se configuram como recursos aplicáveis à Enfermagem Familiar, uma vez que seus objetivos visam aprimorar a qualidade de vida das famílias e, ainda, promover, fortalecer e manter seu bem-estar. O objetivo deste estudo foi refletir sobre os principais conceitos de rede e apoio social, relacionando-os à Enfermagem Familiar para sua aplicação na pesquisa e na prática de enfermagem. Concluise que falta consenso sobre esses conceitos e há necessidade de mais critérios ao empregá-los. O pesquisador ao utilizar a Enfermagem Familiar, deve selecionar, na literatura, os conceitos de rede e de apoio social mais relevantes para se atingirem os objetivos propostos.

DESCRITORES: apoio social; enfermagem familiar; formação de conceito

${ }^{1}$ RN, M.Sc. Student, e-mail: iara_eerp@yahoo.com.br; ${ }^{2}$ Full Professor, Retired, e-mail: smmrocha@eerp.usp.br; ${ }^{3}$ PhD, Faculty, e-mail: lucila@eerp.usp.br. University of São Paulo at Ribeirão Preto, College of Nursing, WHO Collaborating Centre for Nursing Research Development, Brazil 
Family Nursing, based on Health Promotion ${ }^{(1)}$, aims to study families with a view to improving their quality of life. Therefore, various concepts are used that help to understand the family, such as communication, spirituality, religion, roles, among others. In this study, we will only focus on social network and social support concepts. The theoretical framework results from a set of interwoven concepts that construct a representation of the family, permitting the researcher to approach the empirical level.

This theoretical essay results from studies by a research group that has been seeking, through research and practice, a deeper understanding of Family Nursing ${ }^{(2-3)}$. During their activities, members felt the need to improve the definition of social network and social support, considering that Family Nursing literature, although rich, does not offer precise concepts. This gap justifies our objective, which is to reflect on social network and social support concepts, relating them with Family Nursing, with a view to their application in nursing research and practice. The theoretical essay is based on logical and reflexive exposition, besides detailed arguments, with a high level of interpretation and personal judgment ${ }^{(4)}$.

\section{CONCEPTUAL REVIEW}

Literature offers a series of definitions for social support, deriving from qualitative or quantitative studies. In a bibliographic review ${ }^{(5)}$, the author elaborated a broad social support concept with a view to covering its complexity and checking its utility in research. Social support was considered a time-related term, that is, its meaning and significance can vary along the course of life; requires the existence of social relations that vary according to structure, strength, type and some conditions, such as reciprocity, accessibility and confidence; social relations provide for inclusion, as well as emotional, material and cognitive resources, among others; as a result of social bonds, individuals can take somewhat of a distance from their problems; giving information is inherent in all support resources; interactions can occur intentionally or not and can exert a positive or negative influence, which is affected by the acknowledgement of individual needs and how the support is perceived; it depends on characteristics of who offers and receives support ${ }^{(5)}$. In a briefer way, social support can be defined as "any information, either spoken or not, or material help offered by groups or individuals, which we would have systematic contact with, resulting in emotional effects or positive behaviors. This is a reciprocal process, which generates positive effects for the receiving subject, as well as for who offers the support, allowing both to have a greater feeling of control on their lives"(6).

Some authors use social support categories, such as appraisal, emotional, informational and instrumental support ${ }^{(7-8)}$. Appraisal support refers to expressions and feelings of acknowledgement; emotional support refers to affection, love, empathy, respect; the informational category is related to suggestions, information, advice and opinions; and instrumental support to financial help, time dedicated and availability of resources, goods and services ${ }^{(7-8)}$. On the other hand, social support can also be represented by two main types: emotional and instrumental $^{(9)}$.

In another bibliographic review ${ }^{(9)}$, social support was analyzed in terms of complexity and qualified not only in types, but also attributes and antecedents $^{(9)}$, which grants more solid foundations to research using this concept applied to Family Nursing. Attributes are characteristics that remain consistent among different types, while types inherently differ from one another. Examples of attributes are: information, social support as an interpersonal process ${ }^{(6,9)}$ and contextual influence ${ }^{(5,9)}$. Antecedents are conditions established before the start of the social support, such as the event of favorable circumstances for the occurrence of support or the acknowledgement and acceptance by the receiver that (s)he needs help ${ }^{(9)}$. There are studies ${ }^{(10-11)}$ concerned with the quantitative measurement of social support, particularly the assessment of scales, emphasizing the use of well-defined concepts in terms of content, scores, validity and reliability ${ }^{(12)}$.

It is important to distinguish between social support and social network, as these are interwoven but mutually different concepts. Social network refers to the structural or institutional dimension connected with an individual. Examples of network are the neighborhood, religious organization, the health and the school system ${ }^{(7)}$. Social support is found in the personal dimension and constituted by members of this social network who are actually important to the families. Social network is a net of relations that links up different individuals with social bonds, favoring the flow of support resources through these bonds ${ }^{(12)}$. The 
component dimensions of the social network are: size (number of people whom one has social contact with); geographical dispersion (the greater the proximity, the greater the probability of contact); strength of connections (degree of intimacy, reciprocity, expectations of duration and availability, emotional intensity); density and integration among contacts (number of close people); composition and homogeneity of members (degree of similarity among people, such as: age, socioeconomic condition and others); symmetry (degree of reciprocity in relationships); social rooting (individual's identification with his/her environment) ${ }^{(7,12)}$.

\section{SOCIAL SUPPORT: RESOURCE APPLICABLE TO FAMILY NURSING}

Through the range of definitions exposed, it can be perceived that, despite the large number of studies, there is no consensus among researchers about the social support concept. This is probably due to its multiple facets and difficulties to define and measure ${ }^{(13)}$. It is naïve to think that a concept can be developed to the extent of its useful application in all situations $^{(5)}$. As this is a very complex term, researchers need more criteria when using it. Various studies have been dedicated to its definition and, therefore, it should be used with care, so as not to minimize social support to a mere synonym of some kind of help.

It is essential to consider the context the study is developed in, so that the social support approach does not lose its due importance. Coherence is needed between what is studied, the theoretical framework and the method, whether that is qualitative or quantitative. Each researcher has the task of discovering what aspects are important to permit the use of definitions, either in the academic space or in research, intervention and practice ${ }^{(5)}$. Researchers on this theme have issued alerts about the inconsistency of a study when the social support concept is used in a simplistic or erroneous way ${ }^{(5,9,12-14)}$.

The social support concept is part of different theoretical reference frameworks and practice models. In using Family Nursing, the researcher should look at literature and select the social network and social support concepts that cover relevant aspects to achieve the objectives. Family Nursing departs from the premise of care delivery to the family in its cultural context and physical, mental, emotional and social diversities. This care is aimed at promoting the family's health, strengthening its coping mechanisms, granting autonomy through information and favoring well-being, a quality of life that has not been idealized but lies within the child's existential conditions. Thus, the social support concept should be processed by the researcher and neither based on a pre-existing definition, nor on one that is so broad that it tries to cover all literature about the subject. In constructing the component steps of the research method, the attributes of social support need to be detailed, identifying needs, availabilities, network and support indicators, social situation and expected results, in order to permit an understanding of the families' support needs and practice health promotion in an adequate way.

\section{REFERENCES}

1. Bomar PJ. Promoting health in families. Applying family research and theory to nursing practice. Philadelphia: Saunders; 2004.

2. Simpionato E. A enfermagem familiar na promoção da saúde de famílias de crianças com insuficiência renal crônica. [dissertação]. Ribeirão Preto (SP): Escola de Enfermagem de Ribeirão Preto; 2005.

3. Dias J. Promoção de saúde das famílias de docentes de enfermagem: rede, apoio social e papéis na família. [dissertação]. Franca (SP): Universidade de Franca; 2006. 4. Severino AJ. Metodologia do trabalho científico. $22^{\mathrm{a}}$ ed. São Paulo: Cortez; 2002.

5. Williams P, Barclay L, Schmied V. Defining social support in context: a necessary step in improving research, intervention, and practice. Qual Health Res 2004 setembro; $14(7): 942-60$.
6. Valla VV. Educação popular, saúde comunitária e apoio social numa conjuntura de globalização. Cad Saúde Pública 1999; 15(2):7-14

7. Bullock K. Family social support. Conceptual frameworks for nursing practice to promote and protect health. In: Bomar PJ. Promoting health in families. Applying family research and theory to nursing practice. Philadelphia: Saunders; 2004. 8. House JS. Work, stress and social support. Reading, MA: Addison-Wesley; 1981.

9. Finfgeld-Coneet D. Clarification of social support. J Nurs Scholarsh 2005; 37(1):4-9.

10. Moraes TPR, Dantas RAS. Evaluation of social support among surgical cardiac patients: support for nursing care planning. Rev Latino-am Enfermagem 2007 março-abril; 15(2):323-9.

11. Matsukura TS, Marturano EM, Oishi J. O Questionário de Suporte Social (SSQ): estudos da adaptação para o português. Rev Latino-am Enfermagem 2002 setembrooutubro; 10(5):675-81. 
12. Bowling A. Measuring social netwoks and social suport. In: Bowling A. Measuring health. A review of quality of life measurement scales. $2^{a}$ ed. Philadelphia: Open University Press; 2003.

13. Hupcey JE. Clarifying the social support theory-research linkage. J Adv Nurs 1998; 27:1231-421.

14. Hegyvary ST. Editorial clarifying social support. J Nurs Scholarsh 2005; 37(1):287. 